\title{
Heterogeneity of $p 53$ mutational status in the superficial spreading type of early gastric carcinoma
}

\author{
Hiroshi Imamatsu ${ }^{1,2}$, Ken Nishikura ${ }^{2}$, Hidenobu Watanabe 2 , Yoichi Ajioka 2 , Hideki Hashidate 2 , \\ Hiroshi Kashimura ${ }^{1}$, and Hitoshi Asakura ${ }^{1}$ \\ ${ }^{1}$ Third Department of Internal Medicine, Niigata University School of Medicine, Niigata, Japan \\ ${ }^{2}$ First Department of Pathology, Niigata University School of Medicine, Asahimachi-dori 1-757, Niigata 951-8510, Japan
}

\begin{abstract}
Background. The superficial spreading type of gastric carcinoma may originate from either a single cellular clone or from several different clones; this issue remains controversial. Indeed, the $p 53$ gene has been shown to play an important role in gastric carcinogenesis, but there have been only a few reports on the heterogeneity of gastric carcinoma with respect to the $p 53$ gene.

Methods. We analyzed seven cases of the superficial spreading type of gastric submucosal carcinomas (80 lesions; 10 to 17 per case) which showed different histological types and/or different 533 protein staining patterns. Direct sequences of polymerase chain reaction products were used for the analysis.

Results. p53 Gene heterogeneity in mucosal carcinoma lesions was detected in three cases. However, in all of the cases, the $p 53$ mutational pattern was identical to that found in the submucosal carcinoma lesions. In the heterogeneous cases, the mutation in the submucosal carcinoma was one of the mutation patterns found among the mucosal carcinoma lesions. More precisely, the mutational pattern of both submucosal carcinoma lesions and the mucosal lesions located just above them, was identical.

Conclusion. These data suggest that, with regard to the p53 gene, in some superficial spreading types of gastric carcinomas, there are various subclones in the mucosal carcinoma; one of these subclones becomes predominant through clonal selection, and, thus, invades the submucosa.
\end{abstract}

Key words Superficial spreading type of gastric carcinoma p53 Gene $\cdot$ Clonality $\cdot$ Heterogeneity $\cdot$ Clonal selection

\section{Introduction}

The superficial spreading type of early gastric carcinoma (SSEGC) is characterized by a wide, superficial

Offprint requests to: $\mathrm{H}$. Iwamatsu

Received: October 26, 2000 / Accepted: January 25, 2001 spreading of carcinoma cells, with little vertical invasion in depth [1]. In Japan, this type of carcinoma is defined as an early gastric carcinoma when the affected area exceeds $5 \times 5 \mathrm{~cm}^{2}$ [2]. The histogenesis of SSEGC is a controversial issue. The present discussion focuses on the origin of SSEGCs, namely, whether they are monoclonal or multiclonal in origin.

The $p 53$ gene plays an important role in regulating the cell cycle and apoptosis. Previous reports have recorded a $20 \%$ to $60 \%$ frequency for the $p 53$ mutational rate in gastric carcinoma [3-13]. Because it appears at an early stage in gastric carcinogenesis [13], p53 mutation is highly important.

Heterogeneity of $p 53$ mutations has been observed in mucosal carcinomas; however, a monoclonal pattern was observed in invasive lesions (deeper than the muscularis mucosae) in both colorectal carcinomas [14] and esophageal carcinomas [15].

Some cases of SSEGC showed heterogenity as regards the intensity of p53 immunostaining. Overexpression, as observed by p53 immunostaining, is closely associated with $p 53$ gene alterations, especially missense mutations [11]. As far as we know, there have been no reports proving the heterogeneity of $p 53$ mutations in gastric carcinomas, including SSEGCs.

The aim of this study was to determine whether $p 53$ gene mutational status in SSEGCs is heterogeneous in mucosal carcinoma lesions, and homogeneous in submucosal lesions.

\section{Materials and methods}

\section{Materials}

We investigated seven cases of SSEGC (Table 1), based on the criteria used and defined by Kitamura et al. [2]. All of the patients included in the present study underwent surgical resection, without systematic adju- 
Table 1. Clinicopathological features of seven patients whose gastric cancer specimens were examined

\begin{tabular}{|c|c|c|c|c|c|c|}
\hline Case no. & Age (years) & Sex & Gross type $^{a}$ & Histological type ${ }^{b}$ & Depth $^{c}$ & Size $\left(\mathrm{mm}^{2}\right)$ \\
\hline 1 & 65 & M & $\mathrm{IIa}+\mathrm{I}$ & tub $1(\mathrm{~L}$ and $\mathrm{H})$ & $\operatorname{sm} 1$ & $65 \times 55$ \\
\hline 2 & 71 & $\mathrm{~F}$ & $\mathrm{IIa}+\mathrm{IIc}$ & tub $1(\mathrm{~L}$ and $\mathrm{H})$ & sm 1 & $95 \times 73$ \\
\hline 3 & 81 & $\mathrm{~F}$ & $\mathrm{IIa}+\mathrm{IIb}$ & tub $1(\mathrm{H})$, tub $2(\mathrm{H})$, por 2 & sm 1 & $70 \times 58$ \\
\hline 4 & 75 & M & $\mathrm{IIc}+\mathrm{IIa}$ & tub $1(\mathrm{H})$, tub $2(\mathrm{H})$ & $\operatorname{sm} 2$ & $69 \times 50$ \\
\hline 5 & 86 & M & $\mathrm{IIa}+\mathrm{IIc}$ & tub $1(\mathrm{H})$, tub $2(\mathrm{H})>$ por 1 & $\operatorname{sm} 3$ & $105 \times 69$ \\
\hline 6 & 52 & $\mathrm{M}$ & $\mathrm{II} c+\mathrm{IIb}$ & tub $2(\mathrm{H})>\operatorname{tub} 1(\mathrm{H})$, por 2 & sm 3 & $70 \times 50$ \\
\hline 7 & 67 & $\mathrm{~F}$ & $\mathrm{IIb}+\mathrm{IIa}$ & tub $2(\mathrm{H})$ & $\operatorname{sm} 1$ & $60 \times 50$ \\
\hline
\end{tabular}

L, Low-grade atypia; H, high-grade atypia; tub $1(\mathrm{H})$, well differentiated adenocarcinoma with high-grade atypia; tub 1 (L), well differentiated adenocarcinoma with low-grade atypia; tub 2, moderately differentiated adenocarcinoma; por 1, poorly differentiated adenocarcinoma (solid type); por 2, poorly differentiated adenocarcinoma (nonsolid type)

a,b,c Gross type, histological, type, and depth are classified according to the Japanese classification of gastric carcinoma [16]

Table 2. Mutational analysis of $p 53$ in mucosal and Submucosal carcinoma lesions

\begin{tabular}{|c|c|c|c|c|c|c|c|c|}
\hline \multirow{3}{*}{$\begin{array}{l}\text { Case } \\
\text { no. }\end{array}$} & \multicolumn{4}{|c|}{ Mucosal carcinoma } & \multicolumn{4}{|c|}{ Submucosal carcinoma } \\
\hline & \multirow{2}{*}{$\begin{array}{c}\text { No. of } \\
\text { samples }\end{array}$} & \multirow[b]{2}{*}{$\mathrm{IHC}$} & \multirow[b]{2}{*}{ Hist. type } & \multirow{2}{*}{$\frac{\text { Mutated sequence }}{\text { Codon (sequence }{ }^{\text {amino acid }} \text { ) }}$} & \multirow{2}{*}{$\begin{array}{c}\text { No. of } \\
\text { samples }\end{array}$} & \multirow[b]{2}{*}{$\mathrm{IHC}$} & \multirow[b]{2}{*}{ Hist. type } & \multirow{2}{*}{$\frac{\text { Mutated sequence }}{\text { Codon (sequence }{ }^{\text {amino acid }} \text { ) }}$} \\
\hline & & & & & & & & \\
\hline \multirow[t]{5}{*}{1} & 2 & $(+++)$ & tub $1(\mathrm{H})$ & $248\left(\mathrm{CGG}^{\mathrm{Arg}} \rightarrow \mathrm{CAG}^{\mathrm{Gln}}\right)$ & 2 & $(+++)$ & tub $1(\mathrm{H})$ & $248\left(\mathrm{CGG}^{\mathrm{Arg}} \rightarrow \mathrm{CAG}^{\mathrm{Gln}}\right)$ \\
\hline & 2 & $(+++)$ & tub $1(\mathrm{~L})$ & $248\left(\mathrm{CGG}^{\mathrm{Arg}} \rightarrow \mathrm{CAG}^{\mathrm{Gln}}\right)$ & & & & \\
\hline & 1 & $(+++)$ & tub $1(\mathrm{H})$ & 273 (CGT $\left.^{\mathrm{Arg}} \rightarrow \mathrm{CAT}^{\mathrm{His}}\right)^{\prime}$ & & & & \\
\hline & 2 & $(-)$ & tub $1(\mathrm{~L})$ & ND & & & & \\
\hline & 1 & $(-)$ & tub $1(\mathrm{~L})$ & $258\left(\mathrm{CAA}^{\mathrm{Gln}} \rightarrow \mathrm{TAA}^{\mathrm{Stop}}\right)$ & & & & \\
\hline \multirow[t]{10}{*}{2} & 3 & $(+++)$ & tub $1(\mathrm{H})$ & $282\left(\mathrm{CGG}^{\mathrm{Arg}} \rightarrow \mathrm{TGG}^{\mathrm{Trp}}\right)^{\prime}$ & 2 & $(+++)$ & tub $1(\mathrm{H})$ & $282\left(\mathrm{CGG}^{\mathrm{Arg}} \rightarrow \mathrm{TGG}^{\mathrm{Trp}}\right)$ \\
\hline & 1 & $(+++)$ & tub $1(\mathrm{~L})$ & $282\left(\mathrm{CGG}^{\mathrm{Arg}} \rightarrow \mathrm{TGG}^{\mathrm{Trp}}\right)$ & & & & \\
\hline & 1 & $(+++)$ & tub $1(\mathrm{~L})$ & $282\left(\mathrm{CGG}^{\mathrm{Arg}} \rightarrow \mathrm{TGG}^{\mathrm{Tr}}\right)$ & & & & \\
\hline & & & & $278\left(\mathrm{CCT}^{\text {Pro }} \rightarrow \mathrm{TCT}^{\mathrm{Ser}}\right)$ & & & & \\
\hline & & & & $300\left(\mathrm{CCC}^{\text {Pro }} \rightarrow \mathrm{CTC}^{\mathrm{Leu}}\right)$ & & & & \\
\hline & 1 & $(+++)$ & tub $1(\mathrm{~L})$ & $282\left(\mathrm{CGG}^{\mathrm{Arg}} \rightarrow \mathrm{TGG}^{\mathrm{Tr}}\right)$ & & & & \\
\hline & & & & 153 (CCC CCro $^{\text {PC }}$ TCCer $^{\text {Se }}$ & & & & \\
\hline & 1 & $(+++)$ & tub $1(\mathrm{H})$ & ND & & & & \\
\hline & 1 & $(+)$ & tub $1(\mathrm{H})$ & ND & & & & \\
\hline & 2 & $(-)$ & tub $1(\mathrm{~L})$ & ND & & & & \\
\hline \multirow[t]{4}{*}{3} & 4 & $(+++)$ & tub $1(\mathrm{H})$ & $248\left(\mathrm{CGG}^{\mathrm{Arg}} \rightarrow \mathrm{CAG}^{\mathrm{Gln}}\right)$ & 1 & $(+++)$ & tub $2(\mathrm{H})$ & $248\left(\mathrm{CGG}^{\mathrm{Arg}} \rightarrow \mathrm{CAG}^{\mathrm{Gln}}\right)$ \\
\hline & 2 & $(+++)$ & tub $2(\mathrm{H})$ & $248\left(\mathrm{CGG}^{\mathrm{Arg}} \rightarrow \mathrm{CAG}^{\mathrm{Gln}}\right)$ & & & & \\
\hline & 6 & $(+++)$ & por 2 & $248\left(\mathrm{CGG}^{\mathrm{Arg}} \rightarrow \mathrm{CAG}^{\mathrm{Gln}}\right)$ & 2 & $(+++)$ & por 2 & $248\left(\mathrm{CGG}^{\mathrm{Arg}} \rightarrow \mathrm{CAG}^{\mathrm{Gln}}\right)$ \\
\hline & 2 & $(+++)$ & por 2 & ND & & & & \\
\hline \multirow[t]{4}{*}{4} & 1 & $(+++)$ & tub $1(\mathrm{H})$ & ND & & & & \\
\hline & 2 & $(+++)$ & tub $2(\mathrm{H})$ & ND & & & & \\
\hline & 1 & $(-)$ & tub $1(\mathrm{H})$ & ND & & & & \\
\hline & 3 & $(-)$ & tub $2(\mathrm{H})$ & ND & 3 & $(-)$ & tub $2(\mathrm{H})$ & ND \\
\hline \multirow[t]{4}{*}{$5^{\mathrm{a}}$} & 2 & $(+++)$ & tub $1(\mathrm{H})$ & ND & & & & \\
\hline & 4 & $(+)$ & tub $2(\mathrm{H})$ & ND & & & & \\
\hline & & & & & 1 & $(-)$ & tub $2(\mathrm{H})$ & ND \\
\hline & & & & & 4 & $(-)$ & por 1 & ND \\
\hline \multirow[t]{2}{*}{6} & 5 & $(+++)$ & tub $1(\mathrm{H})$ & ND & 2 & $(+++)$ & tub $1(\mathrm{H})$ & ND \\
\hline & 2 & $(+++)$ & por 2 & ND & 1 & $(+++)$ & tub $2(\mathrm{H})$ & ND \\
\hline $7^{\mathrm{a}}$ & 8 & $(+++)$ & tub $2(\mathrm{H})$ & $273\left(\mathrm{CGT}^{\mathrm{Arg}} \rightarrow \mathrm{CAT}^{\mathrm{His}}\right)$ & 2 & $(+++)$ & tub $2(\mathrm{H})$ & $273\left(\right.$ CGT $\left.^{\mathrm{Arg}} \rightarrow \rightarrow \mathrm{CAT}^{\mathrm{His}}\right)$ \\
\hline
\end{tabular}

Histological type is classified according to Japanese classification of gastric carcinoma [16]

IHC, Immunohistochemistry (monoclonal antibody) (PAb-1801); Hist. type, histological type; ND, mutation in exons 5 to 8 not detected ${ }^{a}$ Metastatic carcinomas to the lymph nodes were also available for immunohistochemistry and DNA analysis

vant therapy, in the affiliated hospitals of Niigata University between 1992 and 1998 . The average age of the seven patients (four men; three women) at the time of surgery was 71.0 years. All resected specimens were fixed in $10 \%$ formalin immediately after resection. The entire lesion was serially cut into 4- to 5-mm-thick pieces. Samples were embedded in paraffin. In all cases, immunohistochemistry (IHC) and DNA analysis were conducted. Lymph node metastasis had occurred in two patients, and specimens were available for IHC and DNA analysis (Table 2). Histological examination was performed based on the Japanese Research Society for 
Gastric Cancer classification of gastric carcinoma [16]. Using the system of classification of Watanabe et al. [17], we divided carcinomas into two groups, according to histological and cytological atypia: low-grade carcinoma $(\mathrm{L})$, and high-grade carcinoma $(\mathrm{H})$.

\section{Immunohistochemical analysis of p53 protein}

Three serial, 3- $\mu$ m-thick sections were made from all blocks of each carcinoma. The first section was stained with hematoxylin and eosin (H\&E), the second section was immunostained for p53, using the mouse monoclonal antibody PAb1801 (Oncogene Science I, Manhasset, NY, USA), and the third section was immunostained for Ki-67 (MIB1; Immunotech, Marseille, France). Immunohistochemical staining was performed using streptavidin-peroxidase complex. We used Ki-67 staining as the inner control to prove the adequacy of immunoreactivity, observing nonneoplastic proliferative cells in the neck zone or the germinal center cells of lymph follicles. In the total of seven cases, 80 lesions were analyzed for the p53 protein.

p53-Positive cells were defined as those with brownstained nuclei, regardless of the staining intensity. Expression of p53 protein was classified into four categories: (1) $(+++)$, positive cells distributed throughout most of the lesion; (2) $(++)$, positive cells aggregated in focal area(s); (3) (+), a small number of isolated positive cells were scattered in the lesion; and (4) $(-)$, negative. Overexpression of p53 was defined as $(+++)$ or $(++)$, according to a published study [18].

\section{DNA preparation}

We selected representative sections of carcinoma not only by depth but also by differences in p53 staining patterns and histological and cytological atypia. Six to 14 lesions in each tumor (60 in total) were sampled as mucosal carcinomas, and 2 to 5 lesions from each tumor (20 in total) were sampled as submucosal carcinomas.

DNA extraction from paraffin sections was performed as follows: tissue sections from five to ten serial, nonstained $10-\mu \mathrm{m}$-thick sections from each sample were dewaxed in xylene for $10 \mathrm{~min}$ and rehydrated in $99 \%$ ethanol for $5 \mathrm{~min}$. The lesions were dissected under direct observation with a microscope to avoid contamination of noncarcinoma cells, using commercially available sterilized disposable $25-\mathrm{G} \times 1^{\prime \prime}$ needles $(\Phi 0.5 \mathrm{~mm})$ (Terumo, Tokyo, Japan). There were around 3500-7000 cells, including at least $80 \%$ carcinoma cells, used in each sample; every sample was selected using a DNA isolator PS kit (Wako, Osaka, Japan). DNA was precipitated successively with isopropyl alcohol and with $99 \%$ ethanol and was then dried. Samples were then dissolved in $30 \mu \mathrm{l}$ of sterile water.

\section{Polymerase chain reaction (PCR)}

Oligonucleotide primers were synthesized by Takara Shuzo (Kyoto, Japan). Four fragments of DNA, including exons 5-8 of p53, were amplified, using nested PCR with two sets of primers for each exon. The first and second PCR amplification primers were described previously [19]. The first PCR was performed using a 50- $\mu \mathrm{l}$ reaction mixture containing $50 \mathrm{mM}$ potassium chloride, $10 \mathrm{mM}$ Tris- $\mathrm{HCl}$ ( $\mathrm{pH} 8.0), 0.1 \%$ Triton $\mathrm{X}-100,1.5 \mathrm{mM}$ magnesium chloride, $200 \mu \mathrm{M}$ of each nucleotide (dATP, dCTP, dGTP, dTTP (Takara Shuzo), 20pM of each primer, 2.5 units of Taq DNA polymerase (Promega, Madison, WI, USA), and 1 or $2 \mu \mathrm{l}$ of DNA template. One cycle was performed at $94^{\circ} \mathrm{C}$ for $5 \mathrm{~min}, 55^{\circ} \mathrm{C}$ for $1 \mathrm{~min}$ and $30 \mathrm{~s}$, and $72^{\circ} \mathrm{C}$ for $1 \mathrm{~min}$; followed by 35 cycles at $94^{\circ} \mathrm{C}$ for $1 \mathrm{~min}, 60^{\circ} \mathrm{C}$ for $1 \mathrm{~min} 30 \mathrm{~s}$, and $72^{\circ} \mathrm{C}$ for $1 \mathrm{~min}$; and finally, a 7 -min extension at $72^{\circ} \mathrm{C}$, using the Program Temp Control System (ASTEC; Fukuoka, Japan). The product of the first PCR was used as the template for the second PCR, which was performed under the same conditions; however, during the second PCR, one primer in each set was biotinylated at the $5^{\prime}$ terminal (Takara Shuzo). In each experiment, control reactions containing no DNA samples or human placental DNA (Oncogene Science; Uniondale, NY, USA) were performed simultaneously with the sample reactions. The products of the second PCR were electrophoresed for $20 \mathrm{~min}$ on $4 \%$ agarose gel (NuSieve 3: 1 Agarose; FMC BioProducts, Rockland, ME, USA) using a Mermaid Kit from Bio101 (La Jolla, CA, USA). Informative cases were defined as those with amplified bands on the agarose gels.

\section{Direct sequencing}

All products of the second PCR were sequenced directly, using an Auto Load Solid Sequencing Kit (Pharmacia Biotech, Uppsala, Sweden) and an automated laser fluorescent sequencer (ALF DNA Sequencer II; Pharmacia). The same oligonucleotides as inner PCR primers were labeled fluorescently at their 5' terminals (Takara Shuzo) and used as sequencing primers. To confirm the findings, we analyzed all samples at least twice, in both the sense and antisense directions, using different PCR products obtained from the same samples.

\section{Results}

We detected seven different kinds of p53 mutations: one in exon 5, two in exon 7 , and four in exon 8 ; no mutations were detected in exon 6. All the mutations were transitional mutations, and three occurred in $\mathrm{CpG}$ 


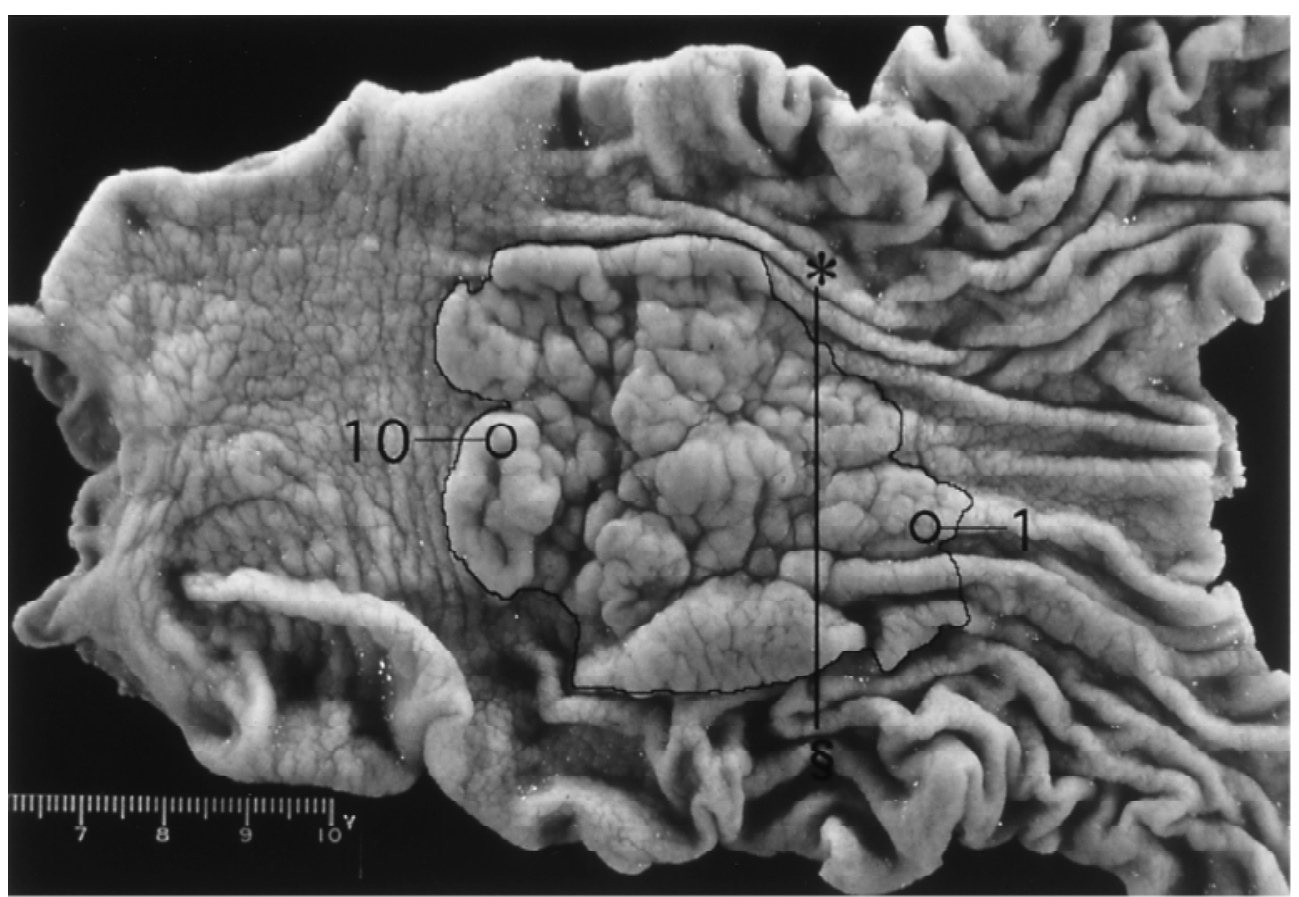

A
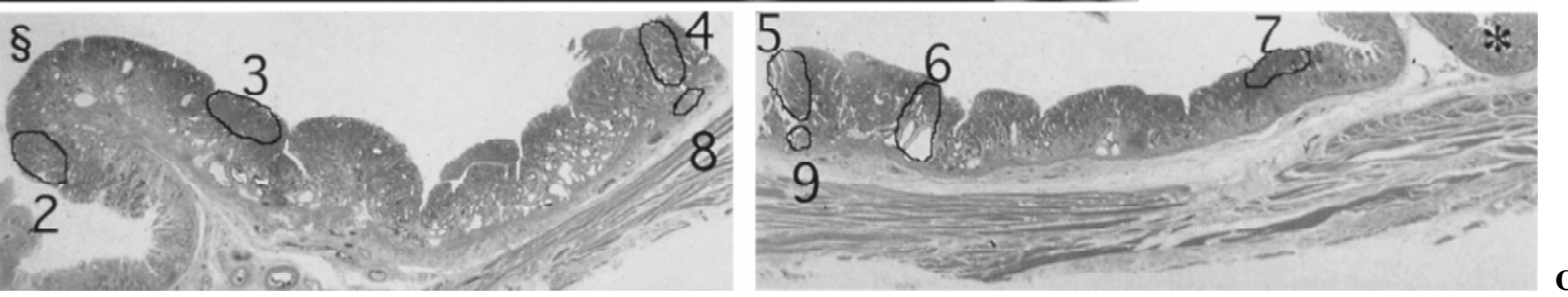

Fig. 1A-C. A representative case (case 1) showing heterogeneity for $p 53$ gene mutation. Specimens were sliced vertically. A Asterisk and $\S$ represent the upper and lower points that appear on the right and left, respectively, in the H\&E sections (B and C). Topographic distributions of the mucosal carcinoma lesions $(1-7,10)$ and submucosal carcinoma lesions $(8,9)$ are shown. DNA was extracted from all of the lesions for $p 53$ mutational analysis

dinucleotide pairs. Point mutations of codon 248 (CGG to $\mathrm{CAG}$ ) and codon 273 (CGT to CAT) were commonly observed in two different cases (Table 2).

We found heterogeneity of $p 53$ gene alterations in mucosal carcinoma lesions in three (cases 1 to 3 ) of the seven cases (Table 2). In case 1, we discovered 8 mucosal carcinoma lesions with four different p53 mutational patterns: 6 lesions occurred with a single mutational pattern (codon 248 or 258 , or 273 ) and 2 lesions appeared without mutations through exons 5 to 8 (Figs. 1, 2). In case 2, we identified 10 mucosal carcinoma lesions with four different p53 mutational patterns: 4 lesions appeared with a single mutational pattern (codon 282), 1 with double mutations (codons 282 and 153), and 1 with triple mutations (codons 282, 278, and 300); 4 lesions without mutations through exons 5 to 8 were also observed. In case 3 , there were 14 mucosal carcinoma lesions: 12 lesions with a same single mutation (codon 248) and 2 lesions were without mutations through exons 5 to 8 .
Two other cases (cases 4 and 5) showed a heterogeneous p53 immunostaining pattern in the mucosal carcinomas, but no gene alteration was detected. There were three lesions with $\mathrm{p} 53$ protein overexpression and four without overexpression in case 4, and two lesions with overexpression and four without overexpression in case 5. Two other cases (cases 6 and 7) showed identical p53 mutations in each tumor; both of them were immunohistochemical and gene alterations.

In all cases, the submucosal carcinoma showed a homogeneous mutational status that was identical to one of the mucosal mutations in the same tumor.

We also analyzed four lesions identified among the lymph node metastases, (one lesion from case 5, and three lesions from case 7). No mutations were found in exons 5 through 8 in case 5 , and the same mutation (codon 273) as in the primary carcinoma was found in case 7.

Most lesions with a $(-)$ or $(+)$ pattern for p53 immunostaining (21 of $22 ; 95.5 \%$ ) did not show any 
A Submucosal carcinoma $(8,9)$

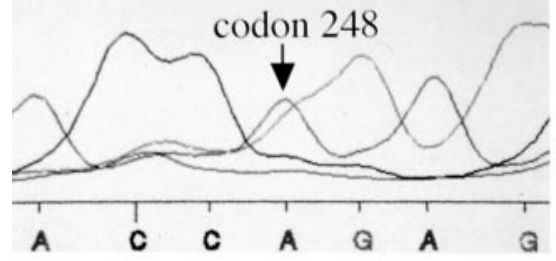

C Mucosal carcinoma (2)

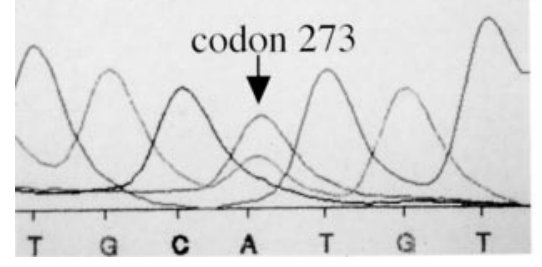

B Mucosal carcinoma (4-7)

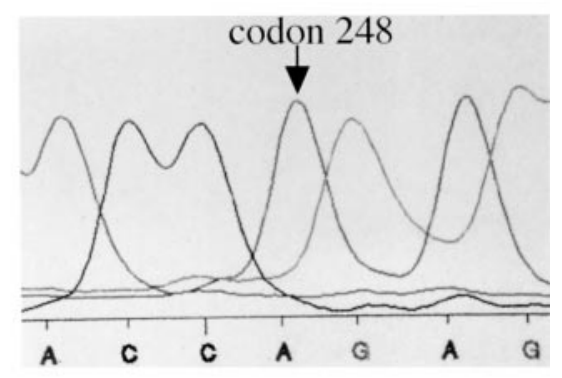

D Mucosal Carcinoma (10)

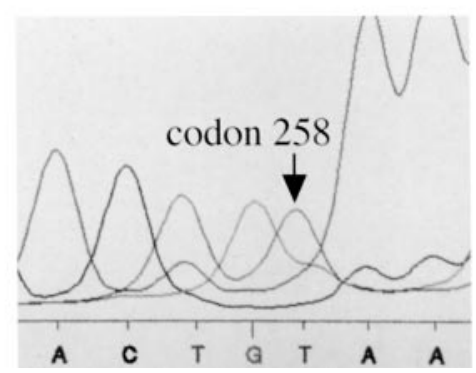

Fig. 2A-D. Mutation of $p 53$ detected by direct sequencing of DNA in case 1 . A Both submucosal carcinoma lesions $(8,9)$ showed the same mutation at codon 248 $\left(\mathrm{CGG}^{\mathrm{Arg}}\right.$ to $\left.\mathrm{CAG}^{\mathrm{Gln}}\right)$. B Mucosal carcinoma lesions (4-7) showed the same mutation at codon $248\left(\mathrm{CGG}^{\mathrm{Arg}}\right.$ to $\left.\mathrm{CAG}^{\mathrm{Gln}}\right)$. This mutation was identical to that of the submucosal carcinoma lesions. C, D Only one mucosal carcinoma lesion $(2,10$, respectively) showed a different mutation at 273 (CGT $^{\text {Arg }}$ to $\mathrm{CAT}^{\text {His }}$ ), and at 258 $\left(\mathrm{CAA}^{\mathrm{Gln}}\right.$ to $\left.\mathrm{TAA}^{\mathrm{Stop}}\right)$, respectively. The other two lesions $(1,3)$ failed to demonstrate any mutations in exons 5 through 8 . Numbers of lesions in parentheses refer to the numbers shown in Fig. 1 mutation in exons 5 through 8 , although one negative lesion showed a nonsense mutation in codon 258 (case 1). Sixty-nine percent of lesions (40 of 58) with p53 protein overexpression revealed $p 53$ gene alterations, while the other $31.0 \%$ of lesions (18 of 58) did not show any mutations through exons 5 to 8 . There was no specific correlation between either the various histological types or the mutational types among the tumors (Table 2).

\section{Discussion}

p53 Mutation is reported to be the most commonly implicated genetic event in gastric carcinogenesis [13]; it is also an early event that is often observed in differentiated types of gastric carcinoma [7,13]. Sequencing of the $p 53$ gene in mammals has revealed five highly conserved domains, four of which fall within exons 5 through 8 , where most of the evolutionarily conserved amino acids are concentrated [20]. Most of the mutations occur within exons 5 through 8 , which we have analyzed in this study. We assessed mutations in the $p 53$ gene by direct sequencing, because single-strand polymorphism analysis often fails to predict $p 53$ mutational status [21].

We found seven different kinds of mutations, all of which were transitional mutations; some of these mutations occurred at the $\mathrm{CpG}$ site. In gastric carcinoma, base transitions were thought to be the most frequent type of genetic change in the $p 53$ gene [6]. Our findings suggest that, even in SSEGCs, base transitions are common genetic alterations, as are those observed in other types of gastric carcinoma. $\mathrm{CpG}$ dinucleotides in the $p 53$ gene seem to be a primary target for mutations associated with dietary carcinogens such as the Nnitroso compounds [22].

Bamba et al. [23] have reported that most SSEGCs are monoclonal; their methodology included using polymorphisms of the X-linked human androgen receptor gene (HUMARA) methods. They examined eight informative cases, and only one case showed heterogeneity. It should be noted that their report did not clarify from which layers the carcinoma cells had been microdissected. In some cases, the number of the lesions examined was small. Thus there remains the possibility that the number of polyclonal cases could be higher than the number they reported. In addition, their study focused on gastric cancers that manifested at least some signet ring cells. In contrast, we focused on gastric cancers that mainly contained well differentiated carcinoma glands. Indeed, there are some differences between these two types of carcinoma. For example, the location of the proliferative zones is different [24], the premalignant lesions differ [25], and some genetic abnormalities differ as well $[13,26]$. Therefore, we inferred that the clonality of gastric cancinomas might differ according to the dominant histological types.

Three reasons are posited to explain why p53 heterogeneity was found in mucosal carcinomas. The first is based on the "field cancerization" theory. SSEGCs may be derived from the collision of different small gastric carcinomas. In many SSEGCs, we found a number of histological types and various kinds of cytological 
atypia; these findings support this reason for $p 53$ heterogeneity in the mucosal carcinomas. The second possible reason is that p53 mutation occurred within a single tumor after clonal expansion. In case 2, we found the same mutation in codon 282 (CGG to TGG) in six mucosal carcinoma lesions; two of these lesions showed other additional mutation(s) in codon 282 (Table 2). The third reason is a combination of the two former explanations.

Kang et al. [27] reported 12 heterogeneous cases of synchronous multiple gastric carcinoma, using $p 53$, $M C C$, and $A P C$ gene analysis. They also suggested that the theory of field cancerization could help to explain gastric carcinogenesis. Further research needs to be done to analyze other genes in order to clarify the clonality of gastric carcinoma. Cho et al. [28] analyzed heterogeneity by means of p53 gene alterations, and showed that there was no correlation between histological type and p53 mutations. In regard to this point, there is no discrepancy between their results and ours.

It should also be noted that there was no $p 53$ heterogeneity in layers deeper than that of the muscularis mucosae carcinomas. In all cases, the submucosal carcinoma showed a homogeneous mutational status that was identical to that of the mucosal mutations in the same tumor. The $p 53$ mutation must have occurred in the mucosal carcinoma, preceding the submucosal invasion, in some SSEGCs. In the mucosal carcinoma lesions, there was a combination of high- and low-grade carcinoma cells, while, in contrast, all of the submucosal carcinoma lesions showed high-grade atypia. We have reported that cells with high-grade atypia in carcinoma readily invade the submucosal layer. We suggest the possibility that a clone with high-grade atypia was selected from among multiple clones within the mucosal carcinoma, and subsequently invaded the submucosal layer.

We examined seven cases of SSEGCs because large carcinoma cells remained in the mucosal layer. But in almost all of the cases, except for cases 5 and 6, a small number of carcinoma cells were found in the invasive lesions. In the future, we hope to analyze more cases with a larger number of carcinoma cells from both mucosaosal and invasive lesions. In order to clarify the p53 clonality of gastric carcinoma, similar analysis regarding early invasive carcinomas, other than SSEGC, needs to be done.

In conclusion, p53 heterogeneity was determined in many cases of SSEGC. It is highly possible that gastric carcinoma cells arise polyclonally during the intramucosal carcinoma stage, and that they later develop into monoclonal populations, while invading the submucosal layer, through clonal selection, with respect to the $p 53$ gene alteration.
Acknowledgments We would like to thank Dr. Shiro Kuwabara for his helpful advice; and Mr. Makoto Yoshida, Ms. Kazuko Kojima, Mr. Naoyuki Yamaguchi, Ms. Ayako Sato, and all of the members of our laboratory staff for their technical assistance.

\section{References}

1. Stout AP. Superficial spreading type of carcinoma of the stomach. Arch Surg 1942;44:651-7.

2. Kitamura K, Yamaguchi T, Okamoto K, Nishida T, Takahashi T. Superficial spreading type of early gastric cancer. Br J Cancer 1996;74:1834-7.

3. Tamura G, Kihara T, Nomura K, Terada M, Sugimura T, Hirohashi S. Detection of frequent $p 53$ gene mutations in primary gastric cancer by cell sorting and polymerase chain reaction single-strand conformation polymorphism analysis. Cancer Res 1991;51:3056-8.

4. Yokozaki H, Kuniyas H, Kitadai Y, Nishimura K, Toda H, Ayhan A, et al. p53 Point mutations in primary human gastric carcinomas. J Cancer Res Clin Oncol 1992;119:67-70.

5. Imazeki $\mathrm{F}$, Omata $\mathrm{M}$, Nose $\mathrm{H}$, Ohta $\mathrm{M}$, Isono K. p53 Gene mutations in gastric and esophageal cancers. Gastroenterology 1992;103:892-6.

6. Renault B, Broek M, Fodde R, Wijnen J, Pellegata NS, Amadori $\mathrm{D}$, et al. Base transitions are the most frequent p53 genetic changes in gastric cancer. Cancer Res 1993;53:2614-17.

7. Uchino S, Noguchi M, Ochiai A, Saito T, Kobayashi M, Hirohashi S. p53 Mutation in gastric cancer: a genetic model for carcinogenesis is common to gastric and colorectal cancer. Int $\mathbf{J}$ Cancer 1993;54:859-64.

8. Strickler JG, Zheng J, Shu Q, Burgart LJ, Alberts SR, Shibata D. p53 Mutations and microsatellite instability in sporadic gastric cancer: when guardians fail. Cancer Res 1994;54:4750-5.

9. Ranzani GN, Leinetti O, Padovan LS, Calistri D, Renault B, Burrel M, et al. p53 Gene mutations and protein nuclear accumulation are early events in intestinal type gastric cancer but late events in diffuse type. Cancer Epidemiol Biomarkers Prev 1995; 4:223-31.

10. Bereanice H, Lim G, Soong R, Grieu F, Robbins PD, House AK, Iacopetta BJ. p53 Accumulation and mutation are prognostic indicators of poor survival in human gastric carcinoma. Int $\mathrm{J}$ Cancer 1996;69:200-4.

11. Seta T, Imazeki F, Yokosuka O, Saisho H, Suzuki T, Koide Y, Isono K. Expression of p53 and p21WAF1/CIP1 proteins in gastric and esophageal cancers. Dig Dis Sci 1998;43:279-89.

12. Tolbert D, Fenoglio-Preiser C, Noffsinger A, De Voe G, MacDonald J, Benedetti J, Stemmermann GN. The relation of p53 gene mutations to gastric cancer subsite phenotype. Cancer Causes Control 1999;10:227-31.

13. Tahara E. Molecular mechanism of stomach carcinogenesis. J Cancer Res Clin Oncol 1993;119:265-72.

14. Kuwabara A, Watanabe H, Ajioka Y, Yasuda K, Saito H, Matsuda $\mathrm{K}$, et al. Alteration of p53 clonality accompanying colorrrectal cancer progression. Jpn J Cancer Res 1998;89:406.

15. Kuwabara S, Ajioka Y, Watanabe H, Hitomi J, Nishikura K, Hatakeyama K. Heterogeneity of p53 mutational status in esophageal squamous cell carcinoma. Jpn J Cancer Res 1998;89:40510.

16. Japanese Research Society for Gastric Cancer, editor. Japanese classification of gastric carcinoma. Tokyo: Kanehara; 1995.

17. Watanabe H, Kato N, Fuchigami T, Sato T, Iwabuchi M, Ajioka $\mathrm{Y}$, et al. Natural history of gastric carcinoma from analyses of microcarcinoma (in Japanese with English abstract). I to cho (Stomach and Intestine) 1992;27:59-67. 
18. Oohashi Y, Watanabe $\mathrm{H}$, Ajioka Y, Hatakey. p53 Immunostaining distinguishes malignant from benign lesions of the gallbladder. Pathol Int 1995;45:58-65.

19. Nakagawa S, Watanabe H, Ajioka Y, Nishikura K, Hitomi J, Hatakeyama K. Archival analysis of p53 protein overexpression and genetic mutation in esophageal squamous cell carcinoma. Acta Med Biol 1996;44:63-9.

20. Soussi T, Fromrntal C, May P. Structural aspects of $\mathrm{p} 53$ protein in relation to gene evolution. Oncogene 1990;5:945-52.

21. Tolbert DM, Noffsinger AE, Miller MA, De Voe GW, Stemmermann GN, MacDonald JS, Fenoglio-Preiser CM. p53 Immunoreactivity and single-strand polymorphism analysis often fail to predict p53 mutational status. Mod Pathol 1999;12:54-60.

22. Poremba C, Yandell DW, Huang Q, Little JB, Mellin W, Schmid $\mathrm{KW}$, et al. Frequency and spectrum of $p 53$ mutations in gastric cancer - a molecular genetic and immunohistochemical study. Virchows Arch 1995;426:447-55.

23. Bamba M, Sugihara H, Okada K, Bamba T, Hattori T. Clonal analysis of superficial depressed-type gastric carcinoma in humans. Cancer 1998;83:867-75.
24. Sugihara H, Hattori T, Fukuda M, Fujita S. Cell proliferation and differentiation in intratramucosal and advanced signet ring cell carcinomas of the human stomach. Virchows Arch A 1987;411: 117-27.

25. Correa P, Hasenszel W, Cuello C, Tannenbaum S, Archer MA. Model for gastric cancer epidemiology. Lancet 1975;II:589.

26. Nomura S, Kaminishi M, Suguyama K, Oohara T, Esumi H. Clonal analysis of isolated intestinal metaplastic glands of stomach using X-linked polymorphism. Gut 1998;42:663-8.

27. Kang GH, Kim CJ, Kang YK, Kim HO, Kim YI. Genetic evidence for the multicentric origin of synchronous multiple gastric carcinoma. Lab Invest 1997;76:407-17.

28. Cho JH, Noguchi M, Ochiai A, Uchino S, Hirohashi S. Analysis of regional differences of $p 53$ mutation in advanced gastric carcinoma: relation to heterogeneous differentiation and invasiveness. Mod Pathol 1994;7:205-11 